\title{
STUDY DESKRIPTIF PROSES MEMBACA PERMULAAN \\ ANAK USIA DINI
}

\author{
Oleh: \\ Adharina Dian Pertiwi \\ Pascasarjana Universitas Negeri Yogyakarta \\ email: dhadharina@yahoo.co.id
}

\begin{abstract}
Abstrak
Membaca permulaan adalah kemampuan bahasa reseptif yang dilalui anak usia dini untuk mempersiapkan ketrampilan membaca anak sebelum memasuki sekolah dasar. Proses membaca permulaan distimulasikan kepada anak sesuai tahapan yang baik, yaitu seperti pengenalan pada huruf vokal dan konsonan kemudian mengeja atau menggabungkan bunyi huruf, suku kata maupun kata sederhana pada anak. Artikel ini bertujuan untuk mengetahui study penelitian deskriptif kemampuan membaca permulaan pada anak TK Kelompok B. Jenis study penelitian ini adalah deskriptif kuantitatif menggunakan metode survei. Teknik pengumpulan data pada study penelitian deskriptif ini menggunakan teknik observasi dengan menggunakan instrumen penelitian lembar observasi checklist. Hasil study penelitian deskriptik ini digunakan untuk menggambarkan kemampuan membaca permulaan pada anak TK Kelompok B. Kemampuan membaca permulaan pada anak TK Kelompok B menunjukkan hasil Berkembang Sesuai Harapan (BSH).
\end{abstract}

Kata kunci: kemampuan, membaca permulaan, kelompok B

\begin{abstract}
Early reading is a receptive language skill undertaken by early-aged children to train their reading skill before enrolling into elementary level. The process of early reading was stimulated to the students based on well organized stages like introduction to the vocals and consonants followed by spelling or constructing sounds of letters, syllables or even simple words to the students. This article is aimed at determining a descriptive research study upon early reading skill of kindergarten students in group B. The study is considered as quantitative descriptive research using survey method. An observation technique using checklist field note was employed to collect the research data. The result of the descriptive research was then used to describe the early reading skill of group B kindergarten students. The result of early reading skill of the group B kindergarten students was categorized into BSH (develop as expected).
\end{abstract}

Keywords: skill, early reading, group B

\section{PENDAHULUAN}

Reyhan, berusia 6 tahun lebih 7 bulan adalah salah satu anak TK Kelompok B yang sudah mampu membaca tulisan dengan baik dan benar. Pengenalan Reyhan pada huruf vokal dan konsonan sangat sempurna, terlihat pada cara pengucapannya ketika dilihatkan kartu huruf dengan cepat serta baik dan benar. Bahkan ketika huruf vokal dan huruf konsonan digabungkan menjadi bentuk suku kata sederhana, Reyhan mampu membacanya dengan baik dan benar pula. Tidak hanya itu, ternyata Reyhan sudah mampu membaca kata sederhana yang mengandung suku kata yang sama atau 
berulang, berbeda, mati bahkan kata yang mengandung suku kata diftong maupun konsonan ganda. Beberapa tahapan membaca permulaan tersebut dilewati Reyhan dengan lancar, mudah, baik dan benar. Selain itu Reyhan mampu membaca kalimat yang mengandung beberapa tahapan sebelumnya, misalnya pada kalimat "kucing itu berlari-lari di dalam aula". Kalimat tersebut dibaca Reyhan dengan lancar tanpa mengeja kembali.

Berbeda dengan kemampuan Ajik, yang berusia 7 tahun lebih 3 bulan dan semestinya sudah memasuki tingkat Sekolah Dasar (SD). Ajik termasuk salah satu anak TK Kelompok B yang masih dikatakan kurang mampu dalam tahapan membaca permulaan. Pengenalan dalam huruf vokal dan huruf konsonan masih terdapat banyak huruf yang belum diketahui serta belum mampu diucapkan oleh Ajik. Beberapa huruf yang belum mampu diucapkan atau diketahui oleh Ajik yaitu pada huruf vokal seperti huruf "e", sedangkan pada huruf konsonan seperti pada huruf "p b, d, l, c, h, dan g". Bahkan Ajik belum mampu mengeja suku kata sederhana yang terdiri dari satu huruf konsonan dan satu huruf vokal misalnya pada suku kata "bi" yang terdiri dari huruf "b" dan "i", bahkan dalam pengucapan huruf "b" dan "d" masih sering terbalikbalik walaupun sudah diberitahu. Pemaparan tersebut membuktikan bahwa kemampuan Ajik dalam membaca permulaan masih kurang berkembang. Karena masih banyak beberapa huruf yang belum mampu Ajik ucapkan, maka Ajik akan mengalami kesulitan pada saat disuruh mengeja suku kata sederhana karena pengetahuan Ajik pada huruf masih sangat minim.

Dari cerita di atas menunjukkan proses membaca permulaan pada anak terdapat tahap-tahapan sehingga anak tidak akan mengalami kesulitan pada tahap berikutnya yang akan mempunyai tingkat kesukaran yang lebih. Tidak dapat dipungkiri pula, bahwa kemampuan anak dalam membaca awal akan sangat berpengaruh terhadap kesiapan anak sebelum memasuki tahap atau jenjang berikutnya. Anak yang sudah mampu dalam tahap membaca awal akan mempunyai kepercayaan diri yang lebih dibandingkan anak yang belum mampu mencapai kemampuan membaca awal dengab baik.

Menurut Carol A \& Barbara A.W (2008: 353-355) membaca merupakan kemampuan mendasar yang harus dimiliki anak untuk memasuki sekolah dasar. Pembelajaran di TK hanya mengajarkan tentang ketrampilan pada anak sebagai persiapan untuk belajar membaca. Pembelajaran bahasa untuk anak usia dini menurut Slamet Suyanto (2005: 171) diarahkan pada kemampuan berkomunikasi, baik secara lisan maupun tertulis (simbolis). Untuk memahami bahasa simbolis, salah satunya anak perlu belajar membaca.

Membaca permulaan adalah sesuatu kesatuan kegiatan yang terpadu mencakup beberapa kegiatan seperti mengenali huruf dan kata-kata, menghubungkannnya dengan bunyi, maknanya, serta menarik kesimpulan mengenai maksud bacaan (Nurbiana Dhieni, 2005: 5,5). Menurut Enny Zubaidah (2003: 9) menyatakan bahwa membaca permulaan atau membaca awal lebih menekankan pada pengenalan dan pengucapan lambang-lambang bunyi yang berupa huruf, kata dan kalimat dalam bentuk sederhana. Dan membaca merupakan aktivitas auditif dan visual untuk memperoleh makna dari simbol berupa huruf atau kata yang meliputi proses decoding atau membaca teknis dan proses pemahaman (Munawir, 2005: 134).

Ada beberapa bunyi huruf yang digunakan dalam bahasa Indonesia yaitu huruf vokal, huruf konsonan, vokal ganda (diftong) dan konsonan ganda. Bunyi huruf vokal terdiri dari a, i, u, e, dan o, kemudian untuk bunyi huruf konsonan tidak semua konsonan bahasa Indonesia dapat diperkenalkan kepada anak usia dini. Menurut Suhartono (2005: 176-190) 
terdapat beberapa bunyi huruf konsonan yang dinyatakan belum tepat diperkenalkan kepada anak usia dini, tetapi untuk anak usia sekolah dasar. Bunyi konsonan yang tepat untuk dikembangkan dan diberikan kepada anak usia dini adalah bunyi konsonan bilabial ( $\mathrm{p}, \mathrm{b}$, dan $\mathrm{m}$ ), dental (n, t, d, l, s, dan r), palatal (c, j, dan $\mathrm{y}$ ), velar (k dan $\mathrm{g}$ ), dan glotal (h). Bunyi huruf vokal ganda (diftong) seperti au, ai, dan oi, sedangkan huruf konsonan ganda seperti ng, ny, sy, dan kh.

Menurut Sabarti Akhadiah, dkk (1993: 11) pengajaran membaca permulaan lebih ditekankan pada pengembangan kemampuan dasar membaca. Kemampuan dasar membaca tersebut yaitu kemampuan untuk menyuarakan huruf, suku kata, kata dan kalimat yang disajikan dalam bentuk tulisan ke dalam bentuk lisan. Jadi anak mulai menggabungkan bunyi huruf menjadi suku kata dan kata yang akan memunculkan makna dari kata tersebut.

Berdasarkan beberapa pendapat yang telah diuraikan, dapat ditegaskan bahwa kemampuan membaca permulaan adalah ketrampilan dasar pada aspek bahasa anak. Yang akan dijadikan bekal untuk memasuki jenjang berikutnya. Dalam membaca permulaan anak dapat mengenal beberapa bunyi huruf, menggabungkan bunyi huruf menjadi suku kata dan kata sehingga muncul makna dalam kata tersebut. Hal ini akan menambah perbendaharaan kata, pemahaman, wawasan pada anak, dan masih dalam lingkup perkembangan bahasa anak bidang keaksaraan.

Menurut Lamb dan Arnold (Farida Rahim, 2008: 16) faktor yang mempengaruhi kemampuan membaca permulaan adalah faktor fisiologis, intelektual, lingkungan, dan psikologis. Faktor fisiologis mencakup kesehatan fisik, pertimbangan neurologis, dan jenis kelamin. Kelelahan merupakan kondisi yang tidak menguntungkan bagi anak untuk belajar. Keterbatasan neurologis dan kekurangmatangan secara fisik juga sebagai salah satu faktor yang menyebabkan anak gagal dalam meningkatkan kemampuan membacanya.

$$
\text { Dalam faktor intelektual, }
$$

disebutkan terdapat hubungan positif antara kecerdasan yang diindikasikan oleh IQ dengan rata-rata peningkatan remedial membaca. Faktor lingkungan mencakup latar belakang pengalaman anak dan status sosial ekonomi keluarga. Sedangkan faktor psikologis mencakup motivasi, minat baca, kematangan sosio, kematangan emosi, dan penyesuaian diri.

Motivasi sebagai pendorong anak untuk melakukan kegiatan membaca. Minat baca adalah keinginan yang kuat disertai usaha yang dilakukan untuk membaca. Pada faktor kematangan sosio, emosi, dan penyesuaian diri mencakup beberapa hal yaitu stabilitas emosi, kepercayaan diri, dan kemampuan berpartisipasi dalam kelompok. Anak yang mudah marah, menangis, menarik diri, mendongkol, dan bereaksi secara berlebihan saat mendapatkan sesuatu, akan mendapat kesulitan dalam pelajaran membaca. Anak yang kurang percaya diri juga tidak bisa mengerjakan tugas yang diberikan kepadanya meskipun tugas itu sesuai dengan kemampuannya.

\section{METODE PENELITIAN}

Penelitian ini merupakan penelitian deskriptif kuantitatif dengan menggunakan metode survey. Penelitian deskriptif menurut Best (dalam Sukardi, 2011: 157) merupakan metode penelitian yang berusaha menggambarkan dan menginterpretasi objek sesuai dengan apa adanya. Analisis kemampuan membaca permulaan dihitung berdasarkan data hasil observasi yang telah dilakukan, kemudian dicari skor dan disimpulkan melalui kriteria yang ditentukan.

Terdapat beberapa indikator yang dijadikan pedoman instrumen yang menggunakan lembar observasi checklist, diantaranya yaitu : (1) Kemampuan mengucapkan bunyi huruf vokal; (2) Kemampuan mengucapkan bunyi huruf 
konsonan; (3) Kemampuan mengeja 1 huruf konsonan dan 1 huruf vokal; (4) Kemampuan mengeja suku kata terbuka (vokal-konsonan-vokal); (5) Kemampuan mengeja suku kata terbuka (konsonanvokal-konsonan-vokal) yang sama; (6) Kemampuan mengeja suku kata terbuka (konsonan-vokal-konsonan-vokal) yang berbeda; (7) Kemampuan mengeja suku kata tertutup (konsonan-vokal-konsonanvokal-konsonan); (8) Kemampuan mengeja suku kata yang mengandung vokal ganda (diftong); dan (9) Kemampuan mengeja suku kata yang mengandung konsonan ganda. Kriteria hasil study penelitian deskriptif dalam kemampuan membaca permulaan pada anak yaitu sebagai berikut:

Tabel 1. Kriteria Dasar Kemampuan Membaca Permulaan

\begin{tabular}{|c|l|c|}
\hline No. & \multicolumn{1}{|c|}{ Kriteria Singat } & Nilai \\
\hline 1. & $\begin{array}{l}\text { Berkembang Sa } \\
\text { Baik (BSB) }\end{array}$ & $61-80$ \\
\hline 2. & $\begin{array}{l}\text { Berkembang Sesuai } \\
\text { Harapan (BSH) }\end{array}$ & $41-60$ \\
\hline 3. & Berkembang (B) & $21-40$ \\
\hline 4. & $\begin{array}{l}\text { Mulai Berkembang } \\
\text { (MB) }\end{array}$ & $0-20$ \\
\hline 5. & $\begin{array}{l}\text { Belum Berkembang } \\
\text { (BB) }\end{array}$ \\
\hline
\end{tabular}

\section{HASIL PENELITIAN DAN PEMBAHASAN}

Hasil penelitian kemampuan membaca permulaan pada anak TK Kelompok B dalam mengucapkan bunyi huruf vokal (a, $\mathrm{i}, \mathrm{u}, \mathrm{e}, \mathrm{o})$ menunjukkan bahwa dari beberapa huruf vokal yang paling dikenal anak yaitu huruf a dengan jumlah persentase $100 \%$. Pada huruf vokal yang memiliki persentase terendah yaitu huruf e dengan jumlah persentase $93 \%$ anak mampu dan $7 \%$ lainnya belum mampu mengucapkan bunyi huruf e. Dalam mengucapkan bunyi huruf konsonan (b, c, d, g, h, j, k, l, m, n, p, r, s, t, dan y) pada anak TK Kelompok B, terlihat bahwa dari berbagai huruf konsonan yang paling mampu diucapkan oleh anak yaitu huruf $\mathrm{c}$ dengan jumlah persentase $96 \%$ atau dengan jumlah 66 anak dari 69 anak, sedangkan huruf yang sukar atau belum mampu diucapkan beberapa anak yaitu huruf g, dengan persentase $68 \%$ anak yang mampu dan $32 \%$ anak belum mampu mengucapkan bunyi huruf g. Kemudian setelah anak mampu mengenal huruf vokal dan konsonan, anak dilihatkan dengan berbagai kartu huruf yang menggabungkan beberapa huruf vokal dan konsonan untuk dieja dari gabungan bunyi huruf tersebut dengan metode fonik.

Sumarti M Thahir (2013: 171-182) berpendapat bahwa setelah memahami aspek fonetik, anak usia dini juga perlu dikenalkan konsep silabi atau suku kata dalam bahasa Indonesia. Suku kata adalah bagian kata yang diucapkan dalam satu hembusan nafas. Pada bahasa Indonesia terdapat dua jenis suku kata yaitu suku kata terbuka dan suku kata tertutup. Suku kata terbuka adalah suku kata yang diakhiri dengan vokal (KV) misalnya pada kata mata (ma-ta) jika diurak dengan pola KV-KV. Maka pada kata mata dua suku katanya adalah suku kata terbuka. Suku kata tertutup adalah suku kata yang diakhiri dengan konsonan (KVK) misalnya pada kata apel (a-pel) jika diurai kata apel terdapat dua jenis pola suku kata yaitu suku kata terbuka pada suku kata [a-] dan suku kata tertutup pada suku kata [-pel].

Suku kata terbuka terbagi menjadi beberapa tahapan yaitu mengucapkan gabungan 1 huruf konsonan dan 1 huruf vokal yang dipilih anak $[\mathrm{m}-\mathrm{a}=\mathrm{ma}]$, gabungan 3 huruf atau VKV [i-b-u=i-bu], gabungan 4 huruf atau KVKV yang sama [g-i-g-i = gi-gi], gabungan 4 huruf atau KVKV yang berbeda [n-a-s-i = na-si]. Hasil reset kemampuan membaca permulaan dalam tahapan suku kata terbuka yaitu sebagai berikut:

Tabel 2. Hasil Kemampuan Membaca Permulaan dalam Suku Kata Terbuka

\begin{tabular}{|c|c|c|}
\hline $\begin{array}{c}\text { Kemampuan } \\
\text { Membaca } \\
\text { Permulaan }\end{array}$ & $\begin{array}{c}\text { Rata- } \\
\text { rata }\end{array}$ & Kategori \\
\hline $\mathrm{KV}$ & 77,39 & $\mathrm{BSH}$ \\
\hline
\end{tabular}




\begin{tabular}{|l|l|l|}
\hline VKV & 66,67 & BSH \\
\hline KVKV (sama) & 76,52 & BSH \\
\hline KVKV (beda) & 69,85 & BSH \\
\hline
\end{tabular}

Dari hasil diatas menunjukkan bahwa kemampuan membaca permulaan pada anak TK Kelompok B dalam tahap suku kata terbuka memasuki kategori Berkembang Sesuai Harapan (BSH). Hasil penelitian menunjukkan bahwa:

1. Kemampuan anak dalam menggabungkan 1 huruf konsonan dan 1 huruf vokal tergantung pengetahuan anak terhadap bunyi huruf vokal maupun konsonan. Anak yang mempunyai pengetahuan huruf belum cukup banyak dari berbagai jenis huruf konsonan maka akan cenderung memilih huruf konsonan yang diketahui atau disukai oleh anak, sedangkan anak yang mempunyai pengetahuan minim tentang huruf vokal dan konsonan akan kesulitan ketika disuruh menggabungkan atau mengucapkan bunyi huruf untuk digabungkan. Jika pengetahuan anak tentang huruf vokal dan konsonan tinggi atau pengetahuan tentang huruf vokal dan konsonan banyak maka akan memudahkan anak dalam membaca atau mengeja suku kata yang terdiri dari satu huruf vokal dan satu huruf konsonan berdasarkan pengetahuan huruf yang sudah dimiliki oleh anak.

2. Kemampuan anak dalam mengucapkan bunyi huruf vokalkonsonan-vokal terlihat lebih sukar diucapkan karena mengandung 3 huruf. Misalnya pada kata i-b-u, maka anak harus mengeja satu demi satu [i$\mathrm{b}-\mathrm{u}=\mathrm{i}-\mathrm{bu}]$. Tahap ini lebih sukar dibandingkan dalam tahap mengucapkan bunyi huruf konsonan dan vokal.

3. Kemampuan anak dalam mengucapkan bunyi huruf KVKV yang sama terlihat lebih mudah dibandingkan tahapan sebelumnya. Anak lebih mudah membaca [gi-gi] daripada [i-bu]. Hal ini dikarenakan anak hanya melihat dua huruf paling depan kemudian mengejanya dan menyamakan untuk huruf berikutnya.

4. Kemampuan anak mengucapkan bunyi huruf KVKV yang berbeda terlihat lebih sukar dibandingkan tahapan sebelumnya. Dalam tahap ini kemampuan membaca permulaan anak masih masuk dalam kategori Berkembang Sesuai Harapan (BSH). Anak lebih sukar membaca karena anak harus mengeja semua huruf terlebih dahulu, jika anak mampu dengan mudah mengeja huruf maka anak akan mengucapkan secara cepat.

Dalam tahap suku kata tertutup tercapai kategori Berkembang (B), itu artinya bahwa kemampuan membaca permulaan anak dalam tahap suku kata tertutup atau KVKVK lebih sukar dibandingkan suku kata tertutup. Kesukaran tersebut terletak pada akhir huruf yang harus menggabungkan 3 huruf sekaligus. Dengan rata-rata $54 \%$ anak mampu dan $46 \%$ lainnya belum mampu.

Hasil kemampuan membaca permulaan anak TK Kelompok B terlihat berbeda ketika mengeja suku kata yang mengandung vokal ganda (pi-sau, au-la, pan-tai, se-poi, dan ha-ri-mau) dan konsonan ganda (si-nga, pa-yung, ku-nyit, se-nyum, dan bu-rung). Anak terlihat belum mampu mengeja suku kata yang mengandung vokal ganda (diftong) dan konsonan ganda. Menurut Suhartono (2005: 187-190) bunyi huruf vokal ganda (diftong) terdiri dari au, ai, dan oi, sedangkan huruf konsonan ganda meliputi ng, ny, sy, dan kh. Slamet Suyanto (2005: 173) berpendapat bahwahuruf "ng", "kh", serta "sy" biasanya menjadi huruf yang sulit untuk dimengerti anak, karena yang lain satu huruf bisa berfungsi kenapa harus dua huruf baru berfungsi. Mungkin akan lebih mudah bagi anak jika dua huruf tersebut diganti satu simbol huruf lain.

\section{KESIMPULAN}


Kemampuan membaca permulaan pada anak TK Kelompok B akan terlihat berdasarkan pengetahuan huruf yang dimiliki oleh anak. Jika anak mampu mengenal berbagai huruf konsonan dan vokal dengan baik dan lancar, maka akan membantu mempermudah anak dalam mengeja. Dan sebaliknya, jika anak belum mampu atau pengetahuan huruf vokal dan konsonan masih rendah maka anak akan kesulitan memasuki tahapan berikutnya seperti mulai mengeja dari suku kata sederhana sampai suku kata yang sulit bagi anak.

Orang tua atau guru harus rajin memberikan stimulasi untuk melatih kemampuan membaca permulaan pada anak dirumah maupun disekolah. Dalam memberikan stimulasi membaca permulaan pada anak, guru dan orang tua harus memberikan tahapan yang sesuai pada kemampuan membaca permulaan anak TK Kelompok B. Stimulasi yang sesuai akan memperlihatkan kemampuan membaca permulaan pada anak sampai pada tahapan yang mana, jikalau terdapat tahapan yang belum mampu dilalui anak maka orang tua dan guru memberikasn stimulasi yang lebih pada tahapan tersebut.

\section{DAFTAR PUSTAKA}

Carol, S dan Barbara A. Wasik. (2008). Pendidikan anak usia dini.(ahli bahasa: Pius Nasar). Jakarta: Indeks.

Farida Rahim. (2008). Pengajaran membaca di sekolah dasar. Jakarta: Bumi Aksara.

Goodchild, R. (2006). Teaching children: the joy of reading. (Alih Bahasa: Sri Meilyana). Jakarta: Elex Media Komputindo.

Mohammad Fauzil Adhim. (2004). Membuat anak gila membaca. Bandung: Mizan Pustaka.

Nurbiana Dhieni dkk. (2005). Metode pengembangan bahasa. Jakarta: Pusat Penerbitan Universitas Terbuka.
Permendiknas No.58. (2010). Standar pendidikan anak usia dini. Jakarta: Kementrian Pendidikan Nasional Direktorat Jenderal Manajemen Pendidikan Dasar Dan Menengah Direktorat Pembinaan TK dan SD.

Slamet Suyanto. (2005). Konsep dasar pendidikan anak usia dini. Jakarta: Depdiknas.

(2005). Pembelajaran untuk anak TK. Jakarta: Depdiknas.

Suhartono. (2005). Pengembangan keterampilan bicara anak usia dini. Jakarta: Depdiknas.

Sukardi. (2011). Metodologi penelitian pendidikan (kompetensi dan praktiknya). Yogyakarta: Bumi Aksara.

Sumarti M Thahir. (2013). Pengembangan bahasa Indonesia tentang kesadaran fonemik (phonemic awarness) untuk anak usia dini (4-5 tahun). Jakarta: Pustakahati Educenter Depok.

Tadkiroatun Musfiroh. (2005). Bermain sambil belajar dan mengasah kecerdasan. Jakarta: Depdiknas.

Theo Riyanto dan Martin Handoko. (2004). Pendidikan pada usia dini. Jakarta: Grasindo. 